innim; these, as already mentioned, have not previously been recorded among potters' marks of the period.

\section{Archæological Research and the Prehistory of India}

AN instructive general view of the results of his journeys of archæological reconnaissance in Southern Persia as a whole was given by Sir Aurel Stein before the East India Association on November 16, when the Marquess of Zetland, Secretary of State for India, was in the chair. As might have been anticipated, Sir Aurel stressed the need for further and intensive archæological investigation, the aim of which should be to throw light on the dark period covering the Aryan invasion and the beginning of the historic era, when Cyrus, in the middle of the sixth century B.c., extended his dominions to Gandhara, including the whole Kabul valley. It is evident, he pointed out, that the Aryan invader, as may be gathered from the Rig-Veda, had been familiar with a considerable portion of the Indo-Iranian borderland long before they settled in the Punjab. Sir Aurel stressed the gratitude due for the archæological discoveries of recent years in the Indus Valley, when so much relating to the period of the Aryan invasion must remain conjectural ; but, he went on to say, his own explorations of the past few years in the great provinces of Kerman, Fars, Khuzistan and Kermanshah, right up to Kurdistan, had left no doubt about an essentially uniform chalkolithic civilization having prevailed here wherever physical conditions permitted of settled life. Yet nowhere on the ground visited had there been found remains filling the wide chronological gap between the chalkolithic mounds traced in such abundance and the numerous burial sites of Baluchistan and Makran, dating at the earliest from the last centuries before our era. Not until sites abandoned much later than Mohenjodaro had been explored could we hope to learn of the actual state of civilization prevailing in the Indus Valley and beyond at the time of the Aryan invasion.

\section{Destruction of Chinese Centres of Learning}

AFTER the great Japanese earthquake of September 1, 1923, when three hundred thousand persons lost their lives, and the buildings of the Imperial University in Tokyo were destroyed, including the loss of about seven hundred thousand volumes in the library, an influential British committee was formed to replace the English section of the library, not only as a token of British sympathy but also as a tribute to the intellectual life of Japan. The calamity which evoked this appeal was a natural one, and unavoidable, but it is ironical now to have to record that Japan itself has destroyed many schools, colleges and universities in China by air raids. We express no opinion upon the causes of the conflict, but we do deplore the barbaric methods of modern warfare which seem to permit no discrimination between combatants and the civilian population, and bring desolation to seats of learning as brutally as to fortified places or other military centres. We are therefore in complete sympathy with the righteous indignation expressed in a telegram organized by "For Intellectual Liberty", and signed in their individual capacity by more than one hundred members of twenty-two British universities, which was sent to the Minister of Education, Nanking, early last month. The replies received from the Shanghai Association of Universities and Colleges, and from representatives in Hankow of ten universities, show deep appreciation of the sympathetic message from England. "In name of world civilization," say the Hankow colleagues, "we thank you for your noble sentiment and moral support. We request you will give unswerving attention to prevent Far Eastern crisis and lend us further support in mobilis. ing all British intellectual and humanitarian forces to the side of our common cause of international justice, which if humanity would exist must prevail."

\section{Jews in Poland}

The Warsaw correspondent of The Times wrote on October 6 describing a system whereby Jewish students are being divided from 'Aryan' students in the lecture rooms of the Warsaw Polytechnic. Part of the benches have been marked for students belonging to a union almost exclusively controlled by 'Aryans', and others for the Jewish students' union, while a few seats for non-union students are left unmarked. The University of Warsaw has its seats numbered, and students sit according to the numbers on their identity cards. All 'Aryan' students, who have even numbers, occupy one half of the room. Unlike the Polytechnic, the University has no unmarked seats. It is stated that other educational establishments in Poland will probably follow suit. In the issue of The Times of November 18, appears a letter signed by Prof. George Barger, Mr. G. D. H. Cole, Mr. T. Edmund Harvey, Dr. Julian Huxley, Prof. Norman Kemp Smith and Prof. J. B. Trend, referring to the apparent surrendering of the authorities of the high schools and universities to the agitation of anti-Semitic students. They state that the Minister of Education, a year ago, gave an assurance that separate benches would never be introduced in the universities. They ask, "Will it enhance the good name or the welfare of the Polish republic if such a spirit of intolerance is officially allowed and deliberately fostered in the very institutions in which are trained our future legislators and administrators?'

\section{Foot-and-Mouth Disease}

THE outbreak of foot-and-mouth disease in the eastern counties of England has produced the usual crop of suggestions, in the form of letters to the daily Press, for dealing with this scourge. It is evidently not widely known that a Foot-and-Mouth Disease Research Committee is in existence, and published a substantial fifth Progress Report on its work so recently as early last summer (see Nature, June 19, p. 1033). Replying to questions on November 15 in the House of Commons, the Minister of Agriculture, Mr. W. S. Morrison, referred to the work of this Committee, and stated that "the most effective 